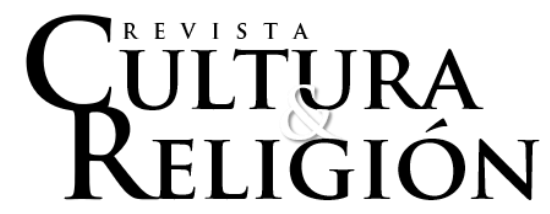

Vol. XV, No 1 (2021) pp. 180-222

Recibido: 5 de mayo, 2020

Aceptado: 18 de abril, 2021

\title{
O MARXISMO CULTURAL NO BRASIL: ORIGENS E DESDOBRAMENTOS DE UMA TEPRIA CONSERVADORA
}
Cultural Marxism in Brazil: origins and developments of a conservative theory

\author{
Wellington Teodoro da Silva* \\ Pontifícia Universidade Católica de Minas \\ Gerais (PUC Minas) \\ ORCID: 0000-0002-4830-7533
}

\author{
Alexandre Sugamosto ** \\ Pontifícia Universidade Católica de Minas \\ Gerais (PUC Minas) \\ ORCID: 0000-0003-4672-6838
}

\author{
Uriel Irigaray Araujo **** \\ Universidade de Brasília - INCT/INEAC \\ ORCID: 0000-0002-2682-3393
}

\section{Resumo}

O presente artigo discute a narrativa sobre o suposto "marxismo cultural" e suas implicações no cenário brasileiro. Por meio da exposição das origens do termo no ambiente intelectual do neoconservadorismo estadunidense, o texto traz à baila as críticas teóricas feitas ao "marxismo cultural". Valendo-se de autores de diversas ramificações intelectuais, o artigo elucida os pontos de contato entre o neoconservadorismo estadunidense e sua vertente brasileira. Expõe, ainda, o trabalho jornalístico e propagandístico dos ideólogos da teoria no Brasil, com destaque para o meio católico, e suas ligações com figuras centrais da administração nacional, bem como a influência da teoria na formulação de 
políticas públicas. $\mathrm{O}$ artigo se encerra com o entendimento de que embora a teoria do "marxismo cultural" seja epistemologicamente confusa, ela possui densidade semântica na medida em que impulsiona determinados projetos de poder.

Palavras-chave: marxismo cultural, neoconservadorismo, Gramsci, Escola de Frankfurt.

\begin{abstract}
This article discusses the theory referred to as "cultural Marxism" and its implications in the Brazilian context. By exposing the origins of the term in the intellectual environment of U.S. neoconservatism, the article discusses the theoretical criticisms of "cultural Marxism". Drawing on authors of various intellectual perspectives, the article examines the similarities between US neoconservatism and its Brazilian counterpart. It also discusses how the Brazilian proponents of this theory use journalism and marketing, especially through a Catholic lens, to tie the theory to the central figures of the national administration, thereby influencing the formulation of public policies. It concludes with the proposition that even though the theory of "cultural Marxism" is epistemologically confusing, it has a certain semantic density and has created a life of its own, being used to justify certain power projects.
\end{abstract}

Keywords: cultural Marxism, neoconservatism, Gramsci, Frankfurt School.

\title{
Introdução
}

Nos últimos anos, a expressão "marxismo cultural” ganhou popularidade no embate ideológico e político brasileiro. No entanto, ao contrário do que o nome possa sugerir, "marxismo cultural" não diz respeito aos estudos culturais de origem marxista e tampouco às contribuições da crítica 
marxista aos elementos artísticos e operativos de uma determinada cultura. $\mathrm{O}$ jargão, na verdade, refere-se a uma teoria ${ }^{1}$ forjada por intelectuais conservadores $^{2}$ estadunidenses na década de 1980 e trazida ao público no começo dos anos 1990. Embora o conservadorismo político seja objeto de inúmeras diatribes, tanto em relação ao seu legado quanto em relação ao seu projeto intelectual, Roger Scruton tenta definir o conservadorismo como uma corrente que surge diretamente

[...] da sensação de pertencimento a alguma ordem social contínua e preexistente e da percepção de que esse fato é importantíssimo para determinar o que fazer. A “ordem” em questão pode ser a de um clube, a de uma sociedade, a de uma classe, a de uma comunidade, a de uma igreja, a de um governo ou a de uma nação [...] (Scruton, 2015, p.54)

Esses ideólogos criaram a expressão "marxismo cultural" para se referirem a um conglomerado heterogêneo de várias tendências ditas progressistas diferentes: pós-estruturalismo, feminismo liberal, movimentos pela liberação sexual e desconstrutivismo, por exemplo. Eles as apresentam de maneira caricatural, vulgarizada, propagandista e, importante, situadas dentro do campo do marxismo. Desse modo, eles podem situar melhor o Mal, o inimigo objetivo (Arendt, 1989), elaborado como objeto de coesão entre

\footnotetext{
${ }^{1}$ Usamos aqui a expressão teoria em seu sentido clássico: "modelo explicativo de um fenômeno ou conjunto de fenômenos que pretende estabelecer a verdade sobre esses fenômenos, determinar sua natureza" (Japiassú \& Marcondes, 1996, p. 260). Se tal teoria se sustenta como conjunto explicativo é justamente o que pretendemos demonstrar ao longo do artigo.

${ }^{2}$ Por "conservadores", designamos um grupo heterogêneo composto por partidos, pensadores etc. que geralmente são identificados com a direita política e que, em comum, caracteriza-se por uma defesa de certa ordem das coisas (seja a atual - geralmente apontada como "estando em perigo" - seja uma suposta ordem perdida). O pensamento que aqui chamamos de conservador defende certas instituições que seriam "orgânicas", entre elas estando o matrimônio, a família, a Igreja e também, às vezes (mas não sempre) o livre mercado, entendido em termos compatíveis com o liberalismo econômico. Contudo, também existem conservadores que defendem o protecionismo ou mesmo o distributismo com redistribuição da propriedade, como, por exemplo, na Inglaterra, G. K. Chesterton (1874-1936) e Hilaire Belloc (1870-1953), os dois principais defensores do chamado distributismo, modelo econômico que contemporaneamente possui defensores nos meios conservadores, em especial, católicos.
}

Revista Cultura \& Religión Vol. XV, 2021 N 1 (enero-junio) 
aqueles que acompanham e/ou venham a acompanhar essa nova visão reacionária de mundo.

Por conta disso, aplica-se o rótulo de "marxismo" a correntes filosóficas díspares com forte influência hegeliana, freudiana, existencialista, neokantiana e idealista, mesmo que essa rotina teórica encontre pouco respaldo nos dados historiográficos sobre o assunto. ${ }^{3}$ Não bastasse a miscelânea cultural abarcada pelo termo, pensadores de diversas linhagens e orientações ideológicas Marcuse, Adorno, Gramsci, Foucault, Lukács, Erich Fromm, Wilhelm Reich, Marx, Freud, Benjamin - são todos acusados de planejarem uma guerra cultural contra o Ocidente e a religião cristã.

O que aconteceu, em suma, é que a cultura tradicional americana, que havia crescido ao longo de gerações de nossas raízes judaico-cristãs ocidentais, foi deixada de lado por uma ideologia. Conhecemos melhor essa ideologia como "politicamente correto" ou "multiculturalismo". É realmente o marxismo cultural, o marxismo traduzido do econômico para o cultural em um esforço que remonta não aos anos 60 , mas à primeira guerra mundial (Lind, 2007, s/ paginação. Tradução nossa).

Conforme essa citação de Lind (2007), parte-se da ideia de que existe a Verdade e que ela está contida na tradição judaica e cristã que engendrou a sociedade ocidental. Esses sujeitos não compreendem estar fundando uma ideia ou imaginário de tradição para se situarem. Eles partem da convicção de que a tradição existe e de que ela, por seu próprio modo de construir civilidade, é fonte da verdadeira virtude que se funda em Deus.

Trata-se da formulação de um imaginário de guerra civilizacional apartada de uma lida propriamente conceitual. Lança-se mão, assim, de sequestros hermenêuticos produtores de narrativas ficcionais que acessam a imaginação por meio de sofismas, os quais dão a impressão de domínio da

\footnotetext{
${ }^{3}$ Para um trabalho acadêmico abrangente sobre o assunto conferir: Callari, A., Cullenberg, S. \& Biewener, C. (ed. 1995). Marxism in the Postmodern Age: Confronting the New World Order. Nova York: Guilford
}

Revista Cultura \& Religión Vol. XV, 2021 Nº 1 (enero-junio) 
realidade. Tal sequestro esvazia o conteúdo original do pensamento do campo adversário e apresenta, assim, outros conteúdos elaborados a partir de narrativas ficcionais.

A palavra comunismo, por exemplo, tem sido usada, ao longo do século $\mathrm{XX}$ até o momento presente, por setores reacionários, como uma espécie de símbolo e não como conceito rigoroso. No símbolo é possível alocar, até de forma contraditória, entulhos psicológicos e construir uma arquitetura de preconceitos que funcionam como ideologia em seu sentido negativo de impedir que a inteligência alcance a efetividade do real; o modo próprio como ele se apresenta. Essa forma de "conceptualização" - que estamos chamando de "simbólica" - guarda paralelos com o que o antropólogo C. Geertz chama de o senso comum: um corpus de ideias organizadas frouxamente para dar sentido à experiência, podendo haver contradições internas (1983, p. 77).

A difusão e certa popularização de tal conceito de "marxismo cultural" é possível em um momento de queda e fragmentação das macroteorias e das crises pelas quais passam as instituições de natureza política e, de modo exemplar, o Estado Nacional Moderno em seus modos afeitos ao século XIX de mediar politicamente a sociedade. A crise da universidade como espaço produtor de saber relevante também é outro fator determinante.

A narrativa produzida pelo saber acadêmico está sendo vencida por ideólogos que combatem a rotina acadêmica numa sanha desqualificadora. As igrejas de larga tradição também sentem a defasagem no mundo atual. Não conseguem traduzir as grandes tradições teológicas de modo que as façam produzir sentido para o mundo contemporâneo. Essa dificuldade é sentida de maneira especial pelo catolicismo brasileiro que ainda não se adaptou ao mundo urbano. Ele acaba abrigando compreensões afeitas a esse imaginário de guerra de civilidade, do bem contra o mal.

As ações desses ideólogos traduzem-se em práticas da antipolítica (Crick, 1981) porque desumanizam os adversários. Não reconhecem neles a condição de interlocutores legítimos, outros relevantes no debate público. 
Transformam-nos em inimigos relevantes reputando-lhes a condição de produtores do mal, inimigos da civilidade e destruidores das verdades que permitem que a sociedade se organize virtuosamente. Essa essencialização torna anêmica e frágil a condição humana do adversário, negando-lhe sua politicidade e, dessa forma, a sua condição de inimigo político conforme a definição de Carl Schmitt (1992). Essa prática não visa ao combate político, mas à higienização.

Para entender os desdobramentos políticos e religiosos dessa teoria, apresentaremos o contexto cultural e histórico de sua origem, a crítica ao conceito e uma breve narrativa de caso do catolicismo brasileiro com foco nas ideias do Padre Paulo Ricardo.

\section{Marxismo cultural: Histórico do termo}

\subsection{Marxismo cultural versus "marxismo cultural" - a análise cultural marxista e seu espantalho}

É importante distinguir entre a teoria do "marxismo cultural" como narrativa conspiratória usada por parte da direita conservadora (tema deste artigo, do qual falaremos em seguida) e, de outro lado, o marxismo cultural como categoria um tanto abrangente usada para referir-se a variadas vertentes de origem marxista - algumas focando também a chamada superestrutura (e não só os aspectos econômicos como enfatiza o marxismo clássico) e outras ainda em diálogo com a psicanálise etc. Iniciamos tratando deste segundo conceito (não conspiratório).

O historiador Dennis Dworkin, por exemplo, usa a expressão "British cultural Marxism" para referir-se a esforços teoréticos (envolvendo um diálogo entre História e estudos culturais) para interpretar e entender as transformações na Grã-Bretanha do pós-guerra (após a Segunda Guerra Mundial), transformações essas que colocavam em xeque certas premissas marxistas clássicas sobre a classe operária (Dworkin, 1997, p. 3). Seria a tradição intelectual em que se situam Edward Thompson e Raymond Williams. 
Dworkin pontua ainda que, em 1979, a teoria pós-estruturalista começava a exercer certa influência em círculos intelectuais socialistas, nos quais ela começava a desafiar a hegemonia marxista e destaca o surgimento de política de "movimentos", citando o feminismo, direitos dos homossexuais, ecologia, antirracismo etc. (1997, p. 165). Note-se que tais movimentos citados não se confundem com o marxismo cultural, embora surjam também em um contexto de certo deslocamento das preocupações de alguns intelectuais da classe e economia para questões culturais.

A chamada análise cultural marxista, por sua vez, abrange a crítica cultural que parte da teoria da hegemonia cultural (geralmente com foco naquela cultura produzida em massa na sociedade capitalista). Essa tradição de análise cultural marxista também tem sido chamada, às vezes, desde os anos 1930, de marxismo cultural (Jamin, 2018, p. 4).

Max Horkheimer (1895-1973) e Theodor Adorno (1903-1969), ambos da chamada Escola de Frankfurt, cunharam a expressão Kulturindustrie (indústria cultural) para descrever a produção padronizada de bens culturais na sociedade capitalista de massas (abrangendo revistas, programas de rádio etc.) (Horkheimer \& Adorno, 2002, p. 107). De acordo com a crítica humanista desses autores, certas necessidades psíquicas humanas relacionadas à criatividade, liberdade etc. não poderiam realizar-se no âmbito da indústria cultural, que cultivaria falsas necessidades psicológicas (a serem atendidas pelos produtos e mercadorias da sociedade capitalista). Assim, tal cultura produzida em massa seria uma ameaça para as Belas Artes, que requerem mais empenho técnico e intelectual.

Dworkin (1997, p. 4), acima citado, também relaciona a Escola de Frankfurt e ainda o pensamento de Antonio Gramsci ao marxismo cultural. O que essas diferentes vertentes teriam em comum, para Dworkin, seria um pensamento que se situa no paradigma marxista, porém, em alguns aspectos, distanciando-se da tradição marxista "mainstream" e do leninismo, sobretudo em sua face supostamente mais "economicista" (1997, p. 4). Para ele, tanto a 
Escola de Frankfurt quanto Gramsci e o que ele chama de marxismo cultural britânico enfatizariam o papel da cultura. Contudo, para além dessas semelhanças, há importantes diferenças - que não cabe detalhar aqui (1997, p. 4).

Por razões de espaço e por ultrapassar nossos objetivos aqui, não nos aprofundaremos em uma discussão sobre o marxismo cultural no sentido do pensamento de diferentes autores marxistas que, de diferentes formas, enfatizaram também elementos não-econômicos (da superestrutura etc.) em suas análises, tais como Lukács, os intelectuais da Escola de Frankfurt e ainda Antonio Gramsci. Ao invés disso, discutiremos o "marxismo cultural" (grafado sempre entre aspas para distinguir os dois termos) tal como é descrito nas narrativas de parte da direita conservadora que popularizou o termo.

\section{2 "Marxismo cultural" - o espantalho}

É bem conhecida a crítica que Adorno (o qual, como vimos, poderia ser descrito como um marxista cultural no sentido acadêmico) faz ao jazz.

Longe de ser um inimigo da "alta cultura" ou da "civilização ocidental", Adorno, musicólogo que, por vinte anos, trabalhou na confecção de um livro sobre Beethoven ${ }^{4}$, criticava - de forma um tanto impiedosa - tanto o jazz quanto a música popular no geral como parte da indústria cultural de qualidade inferior à música erudita - por exemplo, ele nega que o jazz (à época celebrado como grande realização cultural negra) envolva qualquer improvisação genuína ou que tenha trazido qualquer inovação técnica importante (Witkin, 2000, p. 145). Longe de ser uma idiossincrasia ou questão de "gosto musical", tal crítica de Adorno harmoniza-se com sua ideia de princípios de estruturação, os quais o levam a uma defesa "formalista" da arte erudita (Witkin, 2000, p.148).

\footnotetext{
${ }^{4}$ Chamar-se-ia Beethoven - Philosophie der Musik; nunca foi concluído (Socha, 2019, p. 162). 
Hoje, tal crítica seria possivelmente denunciada como "elitista" ou até "fascista" por setores progressistas e talvez Adorno seria "cancelado" $\mathrm{Na}$ verdade, ao longo dos anos 1960, embora à época não se usasse a expressão "cancelamento", Adorno, que também lecionava, entrou em conflito com estudantes universitários diversas vezes: por exemplo, em 1968, quando havia nas ruas, na então Alemanha Ocidental, vários protestos contra o assassinato do ativista Rudi Dutschke pela polícia, Adorno queixou-se dos estudantes que invadiam e interrompiam suas aulas e palestras para protestar e recusou-se a solidarizar-se com eles, mantendo sua autonomia como teórico - ele rejeitou a unidade de teoria e práxis então defendida pelo movimento estudantil. Em uma ocasião, três universitárias aproximaram-se do acadêmico enquanto ele palestrava, seios à mostra, e colocaram pétalas de flores em sua cabeça (MüllerDoohm, 2005, p. 475).

Assim, Adorno poderia ser descrito como um marxista cultural, de acordo com o exposto acima (no sentido em que Dworkin emprega o termo, por exemplo). Porém, quando certo discurso conservador atualmente em circulação refere-se ao mesmo Adorno como "marxista cultural", tal discurso está querendo dizer algo bem diferente. Sem entrar no mérito da discussão (sobre jazz e música popular, por exemplo), é evidente que o Theodor Adorno histórico se apresenta bem diferente do Theodor Adorno imaginado pela narrativa de "marxismo cultural" que circula nos meios conservadores mencionados.

Por exemplo, segundo Olavo de Carvalho (em vídeo de 2019) - de quem se falará mais abaixo - Adorno seria, na verdade, quem verdadeiramente compôs as canções dos Beatles. A hipótese absurda, embora evidentemente sem nenhuma evidência que a corrobore (até porque Adorno morreu nove anos antes da formação da banda Beatles), ainda assim faz sentido dentro da narrativa

${ }^{5} \mathrm{O}$ cancelamento refere-se à contemporânea prática de ostracismo mais comum nos meios universitários, por meio da qual se clama, em protesto a certa atitude ou declaração, que uma determinada pessoa, em represália, seja boicotada das mídias sociais na internet, dos círculos profissionais etc. (Velasco, 2020)

Revista Cultura \& Religión Vol. XV, 2021 Nº 1 (enero-junio) 
geral do "marxismo cultural" que Carvalho expõe, quando ele complementa a afirmação dizendo que se trata de uma celebração do LSD e drogas em geral, com "efeitos devastadores". Tendo-se tal narrativa por pano de fundo, faz sentido - para o público-alvo dessa narrativa - que o verdadeiro autor ou talvez ghost-writer das canções dos Beatles (ou de qualquer outra banda de rock) fosse um intelectual marxista, certamente empenhado em destruir a alta cultura, a civilização ocidental e o cristianismo (para isso, incentivando, se preciso for, o uso de drogas e a "promiscuidade" etc.).

Basicamente, como ficará claro ao longo deste artigo, a narrativa do "marxismo cultural" confunde e mescla movimentos estudantis, pacifistas, pósmodernismo, política identitária, feminismo, movimento LGBT, ambientalismo etc. com marxismo, identificando no "marxismo cultural" de Gramsci e Adorno $^{6}$ a suposta inspiração teórica de todos esses movimentos - movimentos os quais estariam todos orientados para a dissolução do cristianismo e da civilização ocidental.

Ao que tudo indica, a ideia de um "marxismo cultural” é uma espécie de roupagem atualizada para a noção de "bolchevismo cultural" disseminada durante o governo nazista da Alemanha (Jay, 2010, p. 33). De fato, a John Birch Society (JBS), sem necessariamente empregar a expressão "marxismo cultural", já promovia, nos anos 1960, a narrativa de que havia uma conspiração comunista (e judaica) contra a civilização cristã e ocidental como parte do complô da sociedade secreta dos Illuminati (Berlet, 2012, p. 576) ${ }^{7}$. A JBS foi uma organização anticomunista estadunidense fundada em 1958 que se destacou por fazer campanha contra os Civil Rights nos EUA nos anos 1960, denunciando a participação comunista no movimento (Epstein, 1966, p. 9.) .

O próprio William Lind, um dos principais propagadores da narrativa do "marxismo cultural" (de quem se falará mais abaixo), participou, em 15 de

\footnotetext{
${ }^{6}$ Isto é, nas ideias de Gramsci e Adorno (e outros) tal como esses conservadores imaginam que sejam as ideias deles.

${ }^{7}$ Iluministas europeus do século XVIII que, segundo a JBS, ainda estariam ativos no século XX, conspirando para dominar o mundo (Berlet, 2012, p. 576).
}

Revista Cultura \& Religión Vol. XV, 2021 Nº 1 (enero-junio) 
junho de 2002, de uma conferência de Revisionismo do Holocausto, em Washington D. C., evento em que também figuraram simpatizantes declarados do hitlerismo (SPLC, 2002). Embora o próprio Lind afirme não ter dúvidas acerca da veracidade histórica do Holocausto judeu (e tenha ressaltado isso em sua fala no evento citado), sua participação em tal evento mostra como, no início dos anos 2000, havia intersecção entre grupos que poderíamos descrever como antissemitas e proponentes da narrativa do "marxismo cultural".

A intersecção segue ocorrendo no âmbito da chamada "Alt-Right" (Gray, 2018, p. 4). No fundo, o elemento judeu presente na narrativa "original" sobre "marxismo cultural" lhe dá mais sentido e coerência interna: o judeu como o "Outro" por excelência na sociedade europeia agiria, segundo essa visão antissemita, visando a subverter e destruir a sociedade hospedeira, promovendo aquilo que, para uma visão conservadora, seria destrutivo.

No Brasil, Olavo de Carvalho (que defende a civilização "judaicocristã" e tem posicionamentos pró-Israel) "purificou" a narrativa do "marxismo cultural" de seus elementos antissemitas presentes ${ }^{9}$.

No entanto, a origem propagandística do termo "marxismo cultural" e seus posteriores desdobramentos propagandísticos está em um texto chamado New Dark Age: Frankfurt School and 'Political Correctness' publicado por Michael Minnicino em 1992. Minnicino, uma figura intelectual e politicamente inexpressiva, lançou o texto no primeiro número da Revista Fidelio. A revista é ligada ao Schiller Institute, entidade fundada por Helga Zepp-LaRouche (viúva do ativista político, economista e escritor estadunidense Lyndon LaRouche).

${ }^{8}$ A Alternative Right (abreviada Alt-Right) ou a "direita alternativa" é uma expressão que se refere a um amálgama heterogêneo de movimentos de direita e racialistas brancos, além de uma espécie de underground cultural que poderia ser descrito como extremista. A expressão surgiu nos EUA em meados de 2010 e o meio que ela abrange inclui populistas de direita, grupos antimigração etc. (Wendling, 2018, p. 3).

9 Olavo de Carvalho defende uma espécie de alinhamento automático e incondicional com os EUA e com Israel. Consta que o atual Chanceler brasileiro, Ernesto Araújo, foi nomeado por Bolsonaro por indicação de Olavo de Carvalho. Araújo define-se como "discípulo" de Carvalho (Lima, 2019, p, 18). Não por acaso, Bolsonaro prometeu reconhecer Tel-Aviv como a capital de Israel, por exemplo (embora nisso atue também a pressão da bancada evangélica).

Revista Cultura \& Religión Vol. XV, 2021 Nº 1 (enero-junio) 
Segundo informações que estão no site do Instituto (FIDELIO MAGAZINE, sem data), a Revista

dedica-se à promoção de uma nova Renascença Dourada baseada no conceito de 'ágape', ou caridade, como se reflete na criação da beleza artística e, além disso, no domínio científico das leis do universo físico, e a prática da política republicana em benefício do nosso próximo. ${ }^{10}$

No mesmo volume em que está publicado o texto de Minnicino, a revista traz ainda diversos artigos sobre a "Ciência da Música", filosofia, "ciência da economia cristã" e outros tópicos ligados a temas culturais e políticos.

$\mathrm{O}$ editorial do volume, por sua vez, explica as razões dos nomes "Schiller", "Renascença Dourada" e "Fidelio": Schiller teria fornecido os princípios estéticos que norteiam o instituto, a "Renascença Dourada" sendo uma chamada para encontrar a "direção do bem" por meio de uma renovação clássica. Já Fidelio alude a uma ópera de Beethoven, que tem um enredo político: Florestan, herói da peça, é um nobre espanhol que luta pela liberdade e é condenado por seu adversário, Pizarro, a morrer de fome na prisão. O editorial de "Fidelio" compara a figura de Florestan com a de Lyndon LaRouche, que estava preso à época ${ }^{11}$.

LaRouche (1922-2019) publicou centenas de manifestos e livros, foi uma figura participativa, ainda que fortemente contestada (Severo, 2019), no debate político estadunidense, havendo concorrido muitas vezes ao cargo de presidente. Ainda segundo o texto, Lyndon LaRouche, assim como Fidelio, foi condenado à prisão por ter lutado por "uma nova ordem econômica mundial para substituir o injusto sistema monetário internacional” (Wertz, 1992, p. 2). A

10 Texto original: "Fidelio Magazine, published from 1991 to 2006, is dedicated to the promotion of a new Golden Renaissance based on the concept of 'agape', or charity, as that is reflected in the creation of artistic beauty, the scientific mastery of the laws of the physical universe, and the practice of republican statecraft for the benefit of our fellow man " (FIDELIO, p. 1 [p. 3 do PDF]).

11 LaRouche foi solto em 1994 tendo cumprido 1/3 da pena total de quinze anos: https://www.latimes.com/archives/la-xpm-1994-01-27-mn-15995-story.html 
visão de mundo de LaRouche - que influenciou, no Brasil, o político nacionalista Enéas Carneiro (1938-2007) e seu partido PRONA (Gilbert, 2003, p. 6) - era complexa, identificando no conflito entre platonismo e aristotelismo uma espécie de grande chave interpretativa da História mundial (Zuckert \& Zuckert, 2008, p. 12). Suas ideias foram descritas como tendo semelhanças tanto com a "extrema-esquerda" quanto com a "extrema-direita"; porém, ele tem sido mais frequentemente descrito como teórico da conspiração de direita e antissemita (Zuckert \& Zuckert, 2008).

O mencionado texto de Michael Minnicino, o primeiro artigo da revista, começa com uma extensa diatribe contra a fealdade, a sujeira e a baixeza da contemporaneidade. Em seguida, ele elogia as mentes renascentistas e afirma que em algum momento da história humana surgiu uma espécie de "contrarenascença" desenhada como um projeto político "projetado para enfraquecer a alma da civilização judaico-cristã de tal forma que as pessoas acreditassem que a criatividade não era possível, que a adesão à verdade universal era uma evidência de autoritarismo e que a própria razão era, em si mesma, suspeita" (1992, p. 5).

Na sequência, Minnicino deslinda um catálogo de acusações contra os projetos da Escola de Frankfurt e suas consequências na vida intelectual e cultural do Ocidente. Em uma genealogia que começa com Georg Lukács e passa por Marcuse, Adorno, Benjamin, Hannah Arendt, a contracultura das drogas, a Central de Inteligência Americana, os programas de rádio, Umberto Eco, Allen Ginsberg, Timothy Leary, Freud e o programa MK-ULTRA de lavagem cerebral ${ }^{12}$, o libelo descreve as "conexões secretas" que ligariam todos

12 O Projeto MK-Ultra (também grafado MKUltra) era o nome dado a um programa de experiências clandestinas em seres humanos - envolvendo inclusive drogas psicoativas e técnicas de interrogatório - levado a cabo pelo Office of Scientific Intelligence (Departamento de Inteligência Científica) da Central Intelligence Agency, a CIA (a famosa agência de inteligência civil dos EUA) e pelo U.S. Army Biological Warfare Laboratories (USBWL), o Laboratório de Guerra Biológica do Exército dos Estados Unidos. Durou de 1953 a 1973, envolvendo uma série de experimentos secretos, nos quais chegou a ser utilizada tortura criminosa em cobaias humanas estadunidenses e canadenses (Otterman, 2007, p. 24). O documento da sessão mista do comitê de inteligência e do subcomitê de saúde e pesquisa 
esses elementos para a realização de um plano: instaurar uma nova Idade das Trevas na civilização ocidental. Desse modo, o autor conclui que:

[...] a fealdade, tão cuidadosamente nutrida pelos pessimistas da Escola de Frankfurt, corrompeu nossos maiores empreendimentos culturais. Dificilmente se pode encontrar uma apresentação de uma ópera de Mozart que não foi totalmente deformada por um diretor que, seguindo Benjamin e o I.S.R ${ }^{13}$., quer "liberar o subtexto erótico". Você não pode pedir a uma orquestra que interprete Schönberg e Beethoven no mesmo programa, e manter sua integridade para com o último. E quando nossa cultura mais elevada se torna impotente, a cultura popular se torna abertamente bestial (Minnicino, 1992, p.27).

Embora Minnicino não fosse uma figura de muita envergadura intelectual, seu texto parece ter atendido ao escopo natural dos grupos políticos de criar uma narrativa unificadora e um inimigo identificável, como é típico das narrativas conspiracionistas.

Outra figura importante na difusão da teoria do "marxismo cultural" foi o paleoconservador ${ }^{14}$ norte-americano William S. Lind. Além de escritor, é um

científica do Comitê de Recursos Humanos do Senado dos EUA, em 1977 (que detalha alguns desses experimentos), está disponível online em https://publicintelligence.net/ssci-mkultra1977. MK-Ultra é geralmente descrito como um programa de "lavagem cerebral" ou "mind control" (controle mental) e adentrou a cultura popular dos EUA, sendo retratado de forma ficcionalizada em filmes e séries. A existência do programa é um fato histórico fartamente documentado, mas sobre o qual também abundam teorias da conspiração, exagerando sua extensão ou associando toda e qualquer operação de "lavagem cerebral" a este programa.

13 Institute for Social Research da Universidade de Frankfurt (Alemanha). Trata-se do "lar" institucional da chamada Escola de Frankfurt - boa parte dos pensadores desta escola de pensamento de crítica social e filosofia crítica eram de alguma forma filiados ou associados ao referido Instituto. Max Horkheimer tornou-se seu diretor em 1930, imprimindo ao programa do Instituto uma agenda de pesquisa voltada, de forma interdisciplinar, a várias esferas da sociedade (e não mais focada sobretudo nos elementos econômicos). Vide o próprio site do Instituto na seção "Geschichte" (História): http://www.ifs.uni-frankfurt.de/institut/geschichte/ (acesso em 5. Dez. 2020).

${ }^{14}$ Nos EUA, os termos "paleoconservadorismo" e, em contraste, "neoconservadorismo" (ou seja, o "velho conservadorismo" e um "novo conservadorismo") foram cunhados após o início da Guerra do Vietnã para referirem-se à clivagem existente no seio do conservadorismo americano entre isolacionistas (paleoconservadores) e intervencionistas (neoconservadores) (Gottfried, 1993). Assim como o termo "neoconservador" (ou, abreviadamente, neocon) foi 
teórico da chamada "guerra de quarta geração", diretor do American Conservative Center for Public Transportation, tendo escrito ainda diversos textos em que reforça as teses de Minnicino, mas destacando também outro pensador que teria exercido papel fundamental na suposta conspiração para destruir o Ocidente: o marxista italiano Antonio Gramsci (1891-1937).

Segundo Lind, Gramsci teria dito que "os trabalhadores nunca verão seus verdadeiros interesses de classe, como definidos pelo marxismo, até que sejam libertados da cultura ocidental, e particularmente da religião cristã" (Lind, 2000, s/ paginação).

A posição de Gramsci sobre religião, na verdade, é um tanto mais complexa: no começo de sua carreira como jornalista, o pensador italiano, que já foi chamado de "o Weber do marxismo", efetivamente acreditava que o socialismo destruiria o cristianismo, no longo prazo, como nova religião secular - para Gramsci, assim como para Durkheim, a sociedade é um fato moral, cujas fontes normativas estão no fenômeno religioso (Forlenza, 2019, p. 2). Contudo, mais tarde, sob influência da filosofia de Benedetto Croce (1866-1952), passou a defender que as religiões reveladas seriam superadas por uma religião de liberdade (consistindo em uma fé na civilização moderna). Por fim, a partir de 1919, Gramsci chegou a reconsiderar sua posição sobre o fenômeno religioso, analisando-o como um fato social. Sob esse prisma, Gramsci vê então as relações de classes como envolvendo também uma luta entre diferentes concepções de mundo, abrindo assim uma brecha para um tipo de relação orgânica entre marxismo e religião (Nesti, 1975, p. 343). De fato, os Cadernos

mais recentemente recuperado, durante o governo de George W. Bush, para referir-se à ala do Partido Republicano dos EUA mais inclinada ao projeto de "espalhar a democracia no mundo", também o termo "paleoconservador" é ainda usado contemporaneamente para referir-se àqueles conservadores que enfatizam sobretudo um certo nacionalismo econômico, certo protecionismo e uma política migratória mais fechada, além de serem críticos do multiculturalismo e da política externa intervencionista estadunidense (inclusive com suas guerras e intervenções humanitárias) (Foley, 2007). O paleoconservadorismo dos EUA interseciona em larga medida com a chamada Old Right, o paleolibertarianismo, com o chamado populismo de direita e com partes da Alt-Right; por isso, alguns analistas têm visto elementos de paleoconservadorismo no trumpismo (Drolet, 2020).

Revista Cultura \& Religión Vol. XV, 2021 Nº 1 (enero-junio) 
sugerem, repetidamente, que fé e religião são não apenas mais um fator nas sociedades humanas e sim uma espécie de cimento estrutural capaz de fazer, de uma multiplicidade de indivíduos, um grupo social coeso (Forlenza, 2019, p, 4).

Segundo Nesti, a visão de Gramsci sobre a relação entre religião e as classes subordinadas (e a sociedade em geral) vai além do esquema superestrutura-estrutura ou mesmo racionalidade-"regressividade" (1975, p. 353). Para Gramsci, a religião seria uma Weltanschauung dotada de valor cognitivo, que interpreta o "mundo ético", orienta as ações, sendo ainda uma moral que pode fundar certos tipos de solidariedade (Ortiz, 2006, p. 99). Existe em Gramsci, de fato, uma valorização das religiosidades populares (Forlenza, 2019, p, 17).

Em outro texto, William S. Lind busca descrever as origens do "politicamente correto" e traçar algumas estratégias para que os grupos conservadores possam sobreviver aos ataques subversivos perpetuados por aqueles que encampam a doutrina do "marxismo cultural".

Assim, nossa estratégia para desfazer o que o marxismo cultural fez na América tem um certo paralelo com sua própria estratégia, como Gramsci expôs há tanto tempo. Gramsci pediu aos marxistas que empreendessem uma "longa marcha pelas instituições". Nossa contra estratégia seria uma longa jornada para criar nossas próprias instituições. Isso não acontecerá rapidamente ou facilmente. Será o trabalho de gerações - como era o deles. Eles foram pacientes porque sabiam que as "forças inevitáveis da história" estavam do seu lado. Não podemos ser igualmente pacientes e perseverantes, sabendo que o Criador da história está no nosso? (Lind, 2007, s/ paginação)

Num curioso paradoxo, Lind propõe adotar uma estratégia gramsciana para combater os malefícios que Gramsci causou na América (assim como Olavo de Carvalho - e sua rede - faz no Brasil, com uma miríade de editoras, institutos etc.). Ele sugere, no entanto, uma substituição: não mais as forças históricas trabalhariam pela vitória e pela hegemonia, mas o próprio "Criador". 
No que se refere à criação de instituições, Lind não poderia ter sido mais claro: os paleoconservadores e neoconservadores americanos passaram a criar, de fato, diversas instituições, think tanks, revistas e editoras para repelir as investidas do "marxismo cultural".

\subsection{Crítica ao conceito}

Muitos estudiosos e críticos, entretanto, teceram críticas à teoria do "marxismo cultural". De certo modo, a própria intelligentsia marxista nunca deu muita atenção ao termo e tampouco às implicações políticas contidas nos manifestos neoconservadores dos Estados Unidos. O "marxismo cultural" foi considerado, pela maioria dos acadêmicos, como uma mera teoria de conspiração sem valor epistemológico. Alguns acontecimentos, entretanto, mudaram essa percepção geral.

Em 2011, Anders Breivik matou 77 pessoas na Noruega. Em seu manifesto testamentário, que Anders deixou para defender seu gesto, ele usou os termos "marxismo cultural" e guerra cultural mais de 600 vezes nos mais de 1.500 manifestos do texto. Acendeu-se, então, um alerta contra essa teoria que, desde então, tem sido repetidamente chamada de fringe, suprematista e antissemita (Rosenberg, 2019). Salvo raras exceções, o dado teórico tem sido pouco investigado ou criticado.

Evidentemente, o marxismo, no sentido clássico do termo, tornou-se um dos vetores culturais do mundo no século XX por conta de seu notório impacto político e revolucionário. A obra do próprio Marx está fundamentada em eixos específicos de pesquisa e crítica: a concepção dialética da história, a teoria do valor-trabalho, a denúncia das condições miseráveis de vida impostas pelo capitalismo e o papel da luta de classes na construção de uma nova ordem social (Netto, 2009, p. 25). Não há, portanto, nenhum vaticínio sobre a civilização "judaico-cristã” - Marx, aliás, era de família judia - a não ser que se deseje igualar o capitalismo à própria sociedade ocidental. 
Segundo Helen Pluckrose (2018), editora da Revista Areo, aquilo que muitos conservadores chamam de "marxismo cultural" é, na verdade, fruto da política identitária dos intelectuais pós-modernistas e sua fonte, portanto, não é o marxismo. A autora afirma que os intelectuais de direita fazem essa confusão entre marxismo e política identitária para poder, assim, atacar dois flancos simultaneamente: a esquerda econômica e a esquerda identitária - mesmo sendo liberal - ou pós-moderna. Ironicamente, aquilo que os conservadores atacam como "marxismo" poderia talvez ser bem descrito antes como um "liberalismo cultural" que um "marxismo cultural".

Há um setor influente da sociedade que acredita que os discursos dominantes permanecem profundamente racistas, sexistas e homofóbicos. Eles veem muitas evidências da existência do patriarcado, da cultura do estupro, da supremacia branca, da transfobia e do imperialismo. Essas ideias vêm das universidades, mas não da escola de Frankfurt. Eles estão citando os pós-modernistas e, em maior medida, os teóricos do feminismo interseccional, da teoria crítica da raça, da teoria queer e dos estudos póscoloniais ou decoloniais para fazê-lo. (Pluckrose, 2018, s/ paginação)

Dessa forma, a existência de um grupo conspirador forjado para derrubar a "cultura ocidental" não seria uma descrição legítima para falar de eventos culturais díspares que deitam suas raízes nas filosofias de Lyotard, Foucault e Derrida.

No entanto, essa leitura ainda parece supervalorizar ideias e teorias criadas por acadêmicos, enquanto ignora a revolução cultural impulsionada pelo capitalismo tardio e sua teologia econômica (Fusaro, 2012, p.28). Para colocar a ideia em perspectiva, basta notar, por exemplo, que megacorporações transnacionais como Apple, Burger King, McDonald's, Coca-Cola abraçam as agendas comportamentais que seriam fruto da conspiração marxista. De acordo com David Harvey:

[...] o movimento mais flexível do capital acentua o novo, o fugidio, o efêmero, o fugaz e o contingente da vida moderna, em vez dos valores 
mais sólidos implantados na vigência do fordismo. Na medida em que a ação coletiva se tornou, em consequência disso, mais difícil - tendo essa dificuldade constituído, com efeito, a meta central do impulso de incremento do controle do trabalho -, o individualismo exacerbado se encaixa no quadro geral como condição necessária, embora não suficiente, da transição do fordismo para a acumulação flexível. (Harvey, 1992, p. 161)

Por essa razão, alguns autores afirmam que a noção de "marxismo cultural" não passa de um espantalho teórico. A esquerda pós-moderna, por sua vez, não teria nada de "cultural marxista", sequer de "marxista" ou “comunista", mas seria, sim, neoliberalista cultural (Erriguel, 2018). Há, ainda, uma outra crítica relevante. As próprias concepções da Escola de Frankfurt são muito amplas, quando não teoricamente densas e contraditórias, para serem enquadradas no esquema simplista do "marxismo cultural". Um exemplo evidente é a crítica dos frankfurtianos à modernidade que pode ser facilmente adotada por uma perspectiva "antiprogressista" de direita (Erriguel, 2018).

Sendo assim, a teoria do "marxismo cultural" ou "politicamente correto" tem muitos lapsos teóricos e contradições, mas é preciso analisar de que maneira ela se perpetua quando traduzida em gestos políticos.

\section{2 "Marxismo cultural" no Brasil}

Em uma postagem feita no Twitter, o deputado federal Eduardo Bolsonaro (@BolsonaroSP) escreveu: "Vivemos numa guerra cultural e isto é a raiz de todos os problemas. Negar isso é negar a realidade ou demonstrar total ignorância sobre o cenário em que vivemos". E na sequência, "se quiser abrir seus olhos siga, veja os vídeos e leia Olavo de Carvalho @opropriolavo". Tweet, 6:41 AM · May 21, 2019.

A retórica de Eduardo Bolsonaro remete, é claro, ao contexto de guerra cultural conforme preconizado pelos neoconservadores dos Estados Unidos. Ele 
repete, inclusive, a famosa declaração dada por Pat Buchanan numa conferência do Partido Republicano realizada em 1992 (Hopkins, 2017). A menção ao escritor Olavo de Carvalho, por sua vez, não é gratuita. Carvalho foi o responsável por apresentar a teoria do "marxismo cultural" ao público brasileiro.

Em um artigo publicado no jornal o Globo, Olavo de Carvalho, sem mencionar o texto de Minnicino, reproduz boa parte das ideias apresentadas em New Dark Age: Frankfurt School and 'Political Correctness'. O escritor, no entanto, adiciona alguns elementos específicos à narrativa: segundo ele, “Gramsci descobriu a 'revolução cultural', que reformaria o 'senso comum' da humanidade, levando-a a enxergar no martírio dos santos católicos uma sórdida manobra publicitária capitalista" (Carvalho, 2002) e "Lukács, por exemplo, achava a coisa mais natural do mundo repartir sua mulher com algum interessado" (Carvalho, 2002). Finalizando a breve linha histórica apresentada no artigo, Carvalho arremata o texto sentenciando que "por meio do marxismo cultural, toda a cultura transformou-se numa máquina de guerra contra si mesma, não sobrando espaço para mais nada" (2002).

Além de ter lançado alguns livros com comentários sobre filosofia, Olavo de Carvalho ganhou notoriedade por ser considerado uma espécie de conselheiro de Jair Bolsonaro e sua família. Carvalho, inclusive, indicou nomes para ocupar alguns postos estratégicos no governo Bolsonaro. Um deles é o escritor colombiano Ricardo Vélez Rodríguez, que chegou a exercer o cargo de Ministro da Educação no Brasil (01/01/2019-08/04/2019). Em entrevista, Vélez declarou:

O marxismo cultural é uma coisa que faz mal para a saúde. A saúde da mente, do corpo e da alma. Porque secciona o ser humano, o torna massa, o torna coisa. Então, é uma tentativa de buscar uma abordagem cultural que lê a pessoa na sua integralidade, integridade, inteligência e individualidade. Antes de mais nada somos pessoas individualizadas. $\mathrm{O}$ 
marxismo cultural passa a borracha em cima disso e nos considera massa. Nós não somos massa, somos indivíduos (Tajra \& Andrade, 2019).

Ricardo Vélez também declarou, em outra oportunidade, que "essa tresloucada onda globalista, tomando carona no pensamento gramsciano (...), passou a destruir um a um os valores culturais em que se assentam nossas tradições mais caras...” (Saldaña, 2019). Dessa forma, em sua curta passagem pelo Ministério da Educação, Vélez deu diversas entrevistas dando a entender que os problemas educativos do Brasil eram todos derivados do "marxismo cultural" e seu aparelhamento ideológico nas escolas e universidades. Portanto, as políticas públicas educacionais deveriam priorizar essa batalha caso desejassem lograr sucesso na guerra cultural.

Outro episódio relacionado ao artigo de Michael Minnicino aconteceu com Murilo Resende Ferreira, aluno de Olavo de Carvalho, indicado como novo responsável pelo ENEM (Exame Nacional do Ensino Médio). Em seu currículo, ele declarava ser autor de um texto intitulado "A Escola de Frankfurt: satanismo, feiura e revolução" na Revista de Estudos Nacionais (Ferreira, 2017). O artigo, no entanto, tem passagens idênticas às publicadas por Minnicino e disso surgiram, aqui e acolá, acusações de plágio. Murilo se defendeu dizendo que havia produzido uma "tradução adaptada" e que as acusações eram infundadas (Mello, 2019). De todo modo, na tentativa de ressuscitação de "The New Dark Ages..." é notória a pertinência da teoria do "marxismo cultural" para setores neoconservadores brasileiros.

Em um de seus cursos, no entanto, o próprio Olavo de Carvalho relativizou a importância e a veracidade da teoria do "marxismo cultural" que ele mesmo propagara. Na aula 237 do "Curso Online de Filosofia (COF)", gravada em fevereiro de 2014, Carvalho intenta separar os objetivos de Gramsci daqueles propostos pela Escola de Frankfurt. Segundo ele, os frankfurtianos tinham um "espírito corrosivo, negativo e niilista" enquanto Gramsci preservava algo de utópico em suas reflexões. Sendo assim: 
[...] O primeiro problema que eu vejo no conceito de "marxismo cultural", embora, repito, eu mesmo o tenha usado provisoriamente, é que a perspectiva gramsciana não é a mesma da Escola de Frankfurt. A escola de Frankfurt nada tem de utópico (sic). Eles não acreditam em nada. E quando propõem coisas como, sei lá, revolução sexual etc. para eles isso tem um caráter experimental... [...] quando se diz então que o sujeito é um marxista cultural, pode ser qualquer uma dessas duas coisas: ele pode ser um verdadeiro niilista destrutivo como o Herbert Marcuse ou pode ser um utopista como o nosso Jean Wyllys. [...] (Carvalho, 2014)

Ainda que Olavo de Carvalho tenha relativizado o uso da expressão, posteriormente, ele próprio continuou a usá-la de forma conspiracionista em vários de seus textos e, ademais, diversas figuras no meio católico brasileiro valeram-se do "marxismo cultural" para empreender tentativas de reforma religiosa e crítica cultural e política.

\section{3 "Marxismo cultural" e catolicismo no Brasil}

A corrente narrativa do "marxismo cultural" revigorou as narrativas anticomunistas no meio católico reacionário brasileiro. Deu novos elementos para atualizar o anticomunismo católico que, nos tempos que correm, constituise em inimigo imaginário. No período anterior ao golpe de 1964, o anticomunismo católico brasileiro exerceu forte poder de pressão para dar vagas à derrubada de João Goulart e à supressão da ordem constitucional. No entanto, embora o anticomunismo brasileiro não tratasse propriamente do mundo socialista, havia, na mentalidade reacionária, algum tipo de razoabilidade, uma vez que o mundo passava pelo período da guerra fria.

O socialismo do leste aparecia como inimigo poderoso e nada fazia antever a sua derrocada. A revolução cubana surgiu como furacão nas mentalidades latino-americanas, sobretudo entre a juventude. Mesmo nesse momento, a lida dos católicos brasileiros com o tema comunismo estava mais próxima da ficção do que de uma organização conceitual das ideias. Essas 
formulações distantes do mundo real, organizadas no imaginário como simulacro, estão muito próximas da compreensão marxiana de ideologia como formulação de falsas ideias que criam um mundo imaginário como realidade substitutiva daquela que efetivamente acontece do processo histórico. Os setores reacionários compreendiam como comunismo qualquer movimento no sentido da modernização liberal das relações políticas e econômicas no país.

A justaposição entre o estatal e o religioso no padroado brasileiro, por meio do entrelaçamento de ambas as burocracias, permitia que o controle social operasse por essas duas esferas (Monteiro, 2013). Durante séculos os quadros da igreja, embora não fosse uma igreja romanizada, mas estatal, contribuíram para a elaboração das esferas organizativas, políticas e jurídicas. Diversos setores do catolicismo brasileiro, talvez todo ele, seguem se compreendendo como formuladores de modos de organizar a sociedade. Os setores reacionários têm maior zelo por esse lugar de árbitro último do social e do político, incluindo o Estado. Eles operam no tempo presente com referência a um passado idealizado (Koseleck, 2014). Agem no sentido de trazer para o tempo presente um mundo imaginado que teria existido. Esse mundo trata tanto das glórias da igreja mestra do mundo, como, no caso desse estudo, do comunismo. Esse último, no modo como esses setores o descrevem, não pode ser verificado em nenhuma das experiências do socialismo real. Reatualizam essa ficção por meio do chamado "marxismo cultural".

Desse modo, o atual anticomunismo católico é uma poderosa formulação a respeito de um inimigo imaginário por dois motivos: 1) suas formulações não alcançam a efetividade do socialismo real e 2) o socialismo real ruiu.

\subsection{O "marxismo cultural" do Padre Paulo Ricardo}

Sobre esse dado, vale apresentar uma breve análise do discurso de padre Paulo Ricardo de Azevedo Júnior como exemplo do permeio da ficcional narrativa do "marxismo cultural" dentro do ambiente católico. Ele é padre da 
Arquidiocese de Cuiabá e dedica-se às mídias sociais como meio de ampliar o alcance de seu discurso. Em seis vídeos em formato de curso, divididos em aulas de cerca de uma hora cada (2011), trata daquilo que chama de "marxismo cultural" e revolução cultural.

Nesse curso (2011), Padre Paulo Ricardo afirma que está acontecendo uma revolução cultural dentro da Igreja Católica e anuncia que apresentará um estudo sistemático das raízes da Teologia da Libertação e da sua infiltração nessa instituição. Ele entende a revolução como o grande evento diluidor da cultura ocidental e promotora do mal na história. Elabora, assim, uma trama discursiva que associa essa revolução no tempo presente com o comunismo. $\mathrm{O}$ "marxismo cultural" e a revolução cultural contariam com inúmeros atores distribuídos no mundo e estariam em todos os diversos e complexos lugares da sociedade hoje, do mesmo modo que estiveram no século XX. Dentro de um pensamento exemplar de teoria conspiratória, assevera que esses atores internacionalizados operam perfeitamente coordenados para promover seus objetivos. Não há lastro para assegurar essa narrativa conspiratória em nível global; ela é produto de pensamento ficcional que produz sofismas voluntários ou inconscientes.

O tema do muro de Berlim é tratado com temporalidade confusa. Propõe que os modos como os problemas eram tratados pelo comunismo naquele momento permanecem os mesmos (tratados pelo comunismo hoje). Ao contrário de toda razoabilidade investigativa, ensina que o comunismo segue vitorioso atualmente, inclusive camuflado sob a forma do "marxismo cultural". Sua narrativa ficcional avisa que a chamada queda do comunismo teria sido um caso pensado, planejado, afirma, pelos próprios comunistas. Eles teriam compreendido que seria necessário promover uma aparente morte de seu sistema para que seu espírito e ideal se alastrassem. Assim, teriam mudado suas 
estratégias, entre outros motivos, porque os Estados Unidos estavam vencendo a batalha militar ${ }^{15}$.

Vale notar aqui a asserção de Roberto Cipriani (2013) de que a religião é uma espécie de desafio cognitivo porque oferece conteúdo e força para as normas sociais. Confere às pessoas sentidos e significados para o seu estar no mundo. Esse desafio trata da capacidade do pesquisador de entender a capacidade da religião de formular realidades substitutivas. Nessa formidável operosidade do imaginário ficcional do religioso, padre Paulo Ricardo afirma que os comunistas deixaram esse ambiente de ação por terem compreendido que a vitória não viria do campo militar, mas cultural. Volta ao século XIX, afirmando que Karl Marx pensava na implantação da sociedade justa por meio do poder criativo do mal. Argumenta que esse pensamento se devia à dialética marxista que acreditava que a partir do mal surgiria uma ordem superior boa.

Essa alegada guerra cultural promovida pelas forças do mal, por meio da revolução, acontece contra o Deus de Israel e contra o pensamento filosófico grego e o sistema jurídico romano que formaram a Europa e são as colunas da civilização ocidental. Seguindo na estratégia para implantar o comunismo no Brasil, os comunistas, segundo Paulo Ricardo, agiriam contra as instituições e valores que são os pilares mais caros da civilização ocidental. Paulo Ricardo faz aquilo que Álvarez (2017) identifica em seu trabalho sobre os carismáticos na Argentina: busca criar laços com o sagrado para outorgar maior protagonismo ao mundo emotivo e de sensações dos fiéis. Isso ocorreria assim porque sua narrativa ficcional tem como objetivo manejar os sentimentos de ódio contra um inimigo imaginário". Ou seja, pessoas e movimentos reais são combatidos por aquilo que se imagina que sejam. É a mesma engenharia emotiva e sensorial feita pelo partido nazista.

\footnotetext{
${ }^{15}$ Essa é a mesma tese de Olavo de Carvalho, que escreve, por exemplo: "a opinião pública parecia imaginar que o comunismo estava morto e enterrado para sempre, mas na verdade apenas se fazia de morto para assaltar o coveiro" (Carvalho, 2013). Carvalho, por sua vez, baseia-se em autores estadunidenses como Jeffrey Nyquist (2014), cujos textos são regularmente traduzidos para o português no Mídia Sem Máscara, do qual Carvalho é editor (https://midiasemmascara.net/?s=Nyquist).
}

Revista Cultura \& Religión Vol. XV, 2021 N¹ (enero-junio) 204 
$\mathrm{Na}$ estratégia de provocar o mal para produzir o suposto bem, os marxistas, segundo Paulo Ricardo, agiriam contra a família, que eles supostamente odeiam, porque ela está baseada em dois dados que precisam ser eliminados: 1) a propriedade privada e o direito de herança perpétua e 2) a família por significar a opressão patriarcal e ser expressão da ética sexual burguesa. A defesa do casamento gay seria, então, parte da estratégia comunista para destruir a família. Dois homens juntos violam, ainda, a ética burguesa e o patriarcalismo.

Entretanto, as coisas se dão de forma um tanto diferente do que afirma Paulo Ricardo: historicamente, as relações entre o comunismo e a questão homossexual são complexas, assim como as relações entre comunismo e família. A questão da família no marxismo sempre ensejou mal-entendidos e ataques da parte dos anticomunistas - desde os tempos do Manifesto Comunista, os comunistas são acusados de pretenderem "abolir a família". Um imaginário conservador concebe o movimento comunista como, desde sua gênese, em eterno combate contra a família e sempre promovendo o amor livre e a homossexualidade (vistos pelos conservadores como ameaças). Contudo, é conhecida a polêmica entre Lenin e o "movimento feminino", bem como a crítica daquele ao "amor livre" (Zetkin, 1956.)

A instituição da família e o matrimônio foram reconhecidos como unidades básicas da vida social (ou algo análogo) em diferentes constituições de países socialistas, ao longo dos anos. Recentemente, em Cuba, por exemplo, uma proposta de mudança da Constituição que reconheceria o casamento homoafetivo foi deixada de lado, em dezembro de 2018, e o país segue não reconhecendo casamentos nem uniões civis homoafetivos, embora esteja em discussão um novo Código da Família.

Também é amplamente sabido, por exemplo, que, por força de lei (o artigo "muzhelozhstvo"), houve repressão a homossexuais na União Soviética (Valodzin, 2020), assim como existe toda uma discussão historiográfica e uma polêmica sobre o tema em Cuba - em que pese a homossexualidade não ser um 
delito ali, diferentemente do que ocorria na URSS - (Zulendrys, 2010, p. 38) e em outras experiências históricas do chamado "socialismo real".

Ademais, expoentes da própria Escola de Frankfurt, à época, por vezes associavam pejorativamente a homossexualidade ao fascismo e ao antissemitismo, por exemplo (Amidon, 2008, p. 3-5). O próprio sexólogo e psicanalista marxista Wilhem Reich (1897-1957) (que normalmente é também incluído na narrativa conspiratória do "marxismo cultural") era estritamente "heteronormativo" (Kovel, 2010, p. 45).

A narrativa do "marxismo cultural" quanto a todas essas questões só pode se manter internamente coerente justamente porque, em tal narrativa, o movimento LGBT, por exemplo, é considerado "marxismo cultural" quase que "por definição", em que pesem suas origens ideologicamente heterogêneas e as relações frequentemente tensas entre movimento LGBT e marxismo.

Seguindo com o curso de Paulo Ricardo, por seu lado, a Teologia da Libertação utilizaria a linguagem cristã para se infiltrar na Igreja com o objetivo de acabar com os valores cristãos: seria, então, marxismo travestido de cristianismo. Anunciaria o paraíso marxista que deverá acontecer na terra e não no céu. Os meios dessa guerra cultural teriam sido elaborados por Antônio Gramsci, que viveu a crise teórica do marxismo após a I Guerra. Marx teria compreendido o problema da cultura na alienação do proletariado quando escreveu que a religião é o ópio do povo. Assevera o sacerdote que essa crise criou tanto o fascismo quanto o "marxismo cultural".

Paulo Ricardo propõe que a compreensão do marxismo passa pelo fato de que, para ele, não existe verdade. Sabendo-se produtores de falseamentos da realidade, os marxistas recusar-se-iam a debater porque sabem que perderão. Não buscam a verdade, afirma, mas agem denunciando a lógica burguesa. No ambiente de guerra cultural, os marxistas não teriam moralidade precisamente por não buscarem a verdade. 
Maquiavel é outro pensador que recebe a metralha de Paulo Ricardo ${ }^{16}$. Afirma que ele é adorado pela esquerda porque trata a política compreendendo que a moral e o imoral não existem, tampouco conhecendo a ideia do bem e do mal. Apenas existe, para os comunistas (segundo Paulo Ricardo) aquilo que ajuda ou atrapalha a revolução, que é o objetivo final do comunismo. As estratégias de sua realização poderiam então variar segundo o momento. Exemplifica dizendo que o comunismo pode ser contra ou a favor do homossexualismo dependendo de se ele for a favor ou contra a revolução, se ele viabilizar ou impedir a revolução.

Assim, os mesmos comunistas que condenaram os homossexuais por falta de virilidade para construir o socialismo soviético e que prenderam os homossexuais em Cuba, despejariam, atualmente, rios de dinheiro ${ }^{17}$ para apoiar a agenda do movimento homossexual quando este é útil para destruir o ocidente (segundo tal narrativa). Se eles alcançarem os mesmos direitos que os casais heterossexuais, o sistema será supostamente destruído. Essa seria a lógica maquiavélica. O revolucionário, assim, poderia usar batina, brinco, peruca ou qualquer outra coisa, desde que isso ajude a causa revolucionária. O revolucionário combate os cristãos e os burgueses, segundo Paulo Ricardo, porque eles acreditam que existe uma verdade e que ela é maior que a Igreja que não produziu a verdade, mas está ao seu serviço. Segue dizendo que a ideia se constitui na arma e no poder do demônio. O demônio, afinal, mente e a mentira não tem o direito de existir. Portanto, as pessoas que possuem abertura acadêmica e que dizem que podem conviver com qualquer ideia, que dizem estar abertas às diversidades de ideias etc., estão no erro. O cristão deve aceitar a pessoa e não o seu pensamento porque existem ideias que não deveriam existir. Deve-se amar a pessoa e odiar seu erro, seu pecado.

\footnotetext{
${ }^{16}$ Aqui também Paulo Ricardo segue os passos de Olavo de Carvalho (Carvalho, 2016).

${ }^{17}$ Em tal narrativa do "marxismo cultural", não raro bilionários filantropos cujas fundações engajam-se em ação política (Soros, Bill Gates etc.) são descritos como "comunistas". Isso é logicamente possível em tal narrativa por meio do alargamento semântico da palavra "comunismo".
} 
Assevera que o homem moderno vive um sonambulismo suicida. $\mathrm{O}$ esvaziamento teórico desse discurso faz a religião ser reduzida àquilo que Mansilla (2007) recusa que ela seja: sistema cultural, ou, no caso, de falseamento cultural por ela não produzir mediação efetiva com o mundo real. Mansilla (2007) também nega outras realidades na religião que Paulo Ricardo efetiva na sua trama ideológica: jogos linguísticos, metáforas e comunidades imaginárias e um conjunto arbitrário de signos semânticos.

Uma das armas da revolução cultural teria sido convencer o cristão de que ele não odeia nada e de que não quer lutar por coisa nenhuma. O cristão é pacífico, mas não pacifista e não defende a paz custe o que custar. Ele defende, isso sim, a justiça e entende que existe uma paz assassina, injusta e destruidora que luta contra a Igreja (afirma Paulo Ricardo). O revolucionário já sabe o que quer e, assim, usará qualquer meio para chegar a seu objetivo, inclusive a mentira. Por seu lado, o cristão quer a vontade de Deus e deve passar a vida inteira buscando realizá-la. As duas atitudes seriam diferentes. Note-se como os comunistas são retratados ora como relativistas extremos, ora como niilistas.

Padre Paulo Ricardo retoma Gramsci como o grande arquiteto dos planos para se chegar ao socialismo por meio da guerra cultural que prevê que a luta para chegar ao socialismo é a lenta, gradual, invisível e anônima destruição da cultura ocidental. Os marxistas seriam anti-intelectualistas e movidos pelo ódio à cultura ocidental e adotariam, afirma, a estratégia de modificar o senso comum. Compara ainda Stalin e Hitler, assegurando que a questão básica entre eles era apenas o marketing ${ }^{18}$. A mentalidade revolucionária, afirma, muda a estratégia de marketing conforme a situação.

\footnotetext{
${ }^{18}$ Outro tema comum nos escritos de Olavo de Carvalho - a suposta identidade ou equivalência entre nazismo e comunismo (Carvalho, 2008) -, tema o qual, mais uma vez, Carvalho retira de certa literatura conservadora americana (vide, por exemplo, Goldberg, 2009). Esse tema, por sua vez, dialoga em algum grau com a crítica desenvolvida, nesse caso de forma mais sofisticada, por Hannah Arendt em Origens do Totalitarismo, publicado em 1951. Esse conceito arendtiano de totalitarismo também tem sido criticado por diversos autores, como, por exemplo, Žižek (2002, p. 169).
} 
Da mesma forma, prossegue, se a propaganda puder ser feita usando-se linguagem religiosa, eles então entram na Igreja com o objetivo de mudá-la a partir de dentro. Os marxistas que supostamente sempre odiaram a religião saberiam que não vão conseguir implantar o socialismo sem transformar a Igreja numa instituição socialista. Afirma Paulo Ricardo que a crise do marxismo aconteceu na I Guerra quando os trabalhadores que formavam os exércitos lutaram entre si e não contra os patrões. A questão que se impunha aos marxistas naquele momento tratava da alienação dos trabalhadores e de quem os havia alienado. A civilização ocidental teria sido a resposta. Ela havia sido a responsável, por causa de seus valores e instituições, por alienar os trabalhadores.

Segundo Paulo Ricardo, Gramsci elaborou essa compreensão ${ }^{19}$. Por isso, a batalha cultural seria necessária. Avalia que a Escola de Frankfurt é o lugar da produção intelectual no combate do marxismo contra o ocidente. Seu objetivo constituía-se, afirma, em estudar e destruir a civilização ocidental. A maioria das pessoas não associa esses pensadores ao marxismo por serem marxistas heterodoxos, explica. Eles não combateriam no campo econômico, mas cultural. A dissolução do socialismo real teria acontecido justamente para colocar a luta nesse campo. Por isso, segundo Paulo Ricardo, a cultura que vivemos no mundo atual é revolucionária de modo que não a enxergamos enquanto tal. Sequer compreendemos que nosso pensamento é marxista, afirma. É como o peixe que não sabe que está envolto pela água.

Apresenta, ainda, aquilo que considera como a pergunta que importa para os católicos: como podem se livrar do marxismo? Pois quando esses fiéis

19 A narrativa do "marxismo cultural" às vezes atribui a Lukács a ideia de destruir-se a civilização ocidental. Frequentemente, é citada a frase de Lukács: "Quem nos livrará da civilização ocidental?". Olavo de Carvalho mesmo a cita há anos (Carvalho, 2006). Aqui, novamente, Carvalho ecoa certa literatura conservadora estadunidense. William S. Lind faz a mesma citação (https://www.cultureshield.com/wp-content/uploads/2020/05/Cultural_ Marxism.pdf). Trata-se de uma descontextualização de afirmação irônica em prefácio à Teoria do Romance (1916), em uma reflexão sobre a situação da Europa em escombros após a primeira guerra mundial (Dickson, 2020, p. 624)

Revista Cultura \& Religión Vol. XV, 2021 Nº 1 (enero-junio) 
menos esperam, ainda que não percebam, eles pensam de maneira revolucionária. As escolas e as universidades estariam entre os principais campos dessa batalha. Tornaram-se uma versão secularizada e atualizada do movimento gnóstico que acredita que o mundo está malfeito e conseguirá libertar-se pela gnose.

A Escola de Frankfurt constataria a maldade do mundo e agiria para sua destruição, esperando que da destruição surja uma realidade superior. A civilização ocidental seria sua inimiga; sua abordagem seria pessimista e faria uma relação direta entre terror e civilização. Essa postura seria a demência de quem se recusa a acreditar em Deus como verdade. $O$ cristão que acredita na Verdade reconhece nele próprio o problema e compreende que precisa se converter, afirma. A mudança no mundo, então, deve acontecer pela conversão do cristão. Tal Escola proporia a família como um valor fascista (por causa da autoridade do pai). Paulo Ricardo, então, afirma que a Escola de Frankfurt pode ser vista quando o Brasil aprova a lei que pune o pai por punir o filho (referindo-se à Lei $\mathrm{N}^{\mathrm{o}}$ 13.010, de 26 de junho de 2014, conhecida como "lei da palmada", que proíbe o uso de castigos físicos em crianças).

Dentre os movimentos marxistas que realizariam o pensamento dessa escola, em sua luta contra os valores judaicos e cristãos, estariam o movimento hippie $^{20}$, o Rock in Rio e Woodstock. Os norte-americanos, com sua sociedade corrompida, levariam sua corrupção para o mundo inteiro. O marxismo ter-se-ia utilizado dos experimentos das drogas para ajudar a inocular esses valores nas consciências. Como prova de seus argumentos, cita o livro Eros e Civilização de Herbert Marcuse publicado pela primeira vez no ano de 1955.

Paulo Ricardo trata, então, do "marxismo cultural” no Brasil. Afirma que, por ocasião do golpe de 1964, a Igreja Católica era claramente conservadora e anticomunista. Pergunta como pôde, então, haver tanta mudança

\footnotetext{
${ }^{20}$ Ironicamente, uma parte significativa do movimento hippie era anticomunista e, em alguns casos, houve relações entre a extrema-direita e certos grupos hippies, o caso de Charles Manson sendo o mais conhecido.
}

Revista Cultura \& Religión Vol. XV, 2021 Nº 1 (enero-junio) 
com a Teologia da Libertação e as transformações internas pós-Concílio Vaticano II. Ele fia-se na compreensão de que os militares se ocuparam do comunismo armado sem se atentarem que, naquele momento, a estratégia dos comunistas era a cultural e não mais a militar (novamente, isso é possível para Paulo Ricardo porque ele considera toda a contracultura, movimento hippie etc. como sendo "marxistas culturais").

Paradoxalmente, a repressão da ditadura teria permitido o crescimento da cultura comunista no país em proporções nunca vistas. Os militares chegaram a subsidiar o crescimento do comunismo cultural ao franquearem as universidades aos marxistas e darem dinheiro para as publicações comunistas. Assegura que, segundo os próprios comunistas, as publicações marxistas nunca tiveram tanto sucesso quanto na ditadura.

Explica essa teoria afirmando que a cabeça liberal dos militares exigia dois lados. Refere-se àquilo que chama de teoria da panela de pressão de Golbery do Couto e Silva. O sistema precisava de válvulas de escape para não explodir. Por isso, as universidades teriam sido "entregues" aos comunistas. Os militares não sabiam que estavam dando o lugar privilegiado para a nova estratégia cultural do comunismo internacional, afirmam. Eles não estavam prontos para identificar a realidade do "marxismo cultural". A presença dos órgãos de segurança nas universidades era apenas para investigar professores que pudessem falar e promover a luta armada, a invasão de terra e coisas do tipo.

As novelas da Rede Globo também seriam produtos do "marxismo cultural" e da Escola de Frankfurt. São produtos da sociedade decadente capitalista. Os dois maiores escritores de novelas - Dias Gomes e Janete Clair seriam comunistas e promoveriam o "marxismo cultural" usando o liberalismo de Roberto Marinho. Acreditar-se-ia que a opressão faria o sistema explodir. Como isso não aconteceu, os comunistas teriam utilizado a inveja, sentimento humano básico. O setor cultural do marxismo, por meio de Pierre Bourdieu, teria contribuído para essa trama ao criar o termo "excluídos". Por meio desse 
termo, a inveja seria utilizada como combustível da revolução. Padre Paulo Ricardo afirma que antes da ação do "marxismo cultural" as pessoas eram resignadas. $\mathrm{O}$ pobre morava em uma casa de papelão na favela e não reclamava. Nos tempos que correm até a classe média é revoltada.

Por fim, Paulo Ricardo afirma que essa guerra cultural é conduzida por pessoas que sabem que estão fazendo algo lento e gradual. A sociedade brasileira não percebe que está sendo manipulada em sua mentalidade e pensa que estamos no desenvolvimento natural da sociedade. Os "marxistas culturais" conseguiram dominar o setor da sociedade chamado por Pierre Bourdieu de classe falante, que é a responsável pela produção da cultura. Assegura que as universidades, principalmente as católicas, formam seus alunos pela cartilha do "marxismo cultural". Desde a matemática até o direito, a universidade formaria pelo ódio ao cristianismo e especificamente ao catolicismo.

\section{Considerações finais}

O "marxismo cultural" e a revolução cultural não possuem valores epistemológicos. Foram formulados em ambientes sem validação de outros teóricos ou comunidades epistêmicas que pudesse oferecer adequada crítica histórico-conceitual. Constituem-se em narrativas que se apresentam como se fossem construídas com recursos de método e conhecimento suficientes para lhes dar a condição de teorias.

Foram elaboradas com fins de orientação política da realidade e operam modos semelhantes aos que serviram à formulação dos inimigos objetivos das experiências totalitárias, conforme descrito por Hannah Arendt (1989). Paradoxalmente, usam os mesmos procedimentos de criar inimigos conforme o nazismo e o bolchevismo, experiências que afirmam combater.

Ao pretender-se descrever e analisar as narrativas de Lind, Olavo de Carvalho e o Padre Paulo Ricardo sobre o que eles entendem por "marxismo cultural", existe a tentação de exoticizá-las ao extremo, tamanha é a incoerência

Revista Cultura \& Religión Vol. XV, 2021 Nº 1 (enero-junio) 212 
teórica e histórica. Contudo, a eficácia retórica dessas narrativas também reside em certas ansiedades e alguma concretude ocasional, ainda que distorcida.

Tem existido, de fato, certo vácuo no pensamento marxista clássico em se tratando de desenvolver tratamentos teoréticos do fenômeno religioso que deem conta dos amplos encontros entre marxismo e religiosidade. Isso se deve, em parte, ao fato de que o entendimento marxista clássico da transição ao socialismo concebe a luta pelo socialismo como sendo uma radicalização do próprio processo capitalista de modernização e racionalização (emancipando a humanidade das forças da natureza). Tal processo de racionalização, contudo, seria, de modo paradoxal, parcialmente obstruído por certos aspectos da própria sociedade capitalista, como sua falta de planejamento racional da vida econômica. Portanto, tal processo só se poderia completar após uma subordinação dos meios produtivos à administração racional, assim subordinando tanto as forças naturais quanto sociais à razão humana. O surgimento da própria Teologia da Libertação não deixa de ser, em algum grau, uma ruptura com tal tradição de pensamento, permitindo uma "reteorização" do fenômeno religiosos em termos marxistas - contudo, por razões de espaço e escopo, não convém aprofundar-se na questão aqui.

A questão é que, longe de haver uma conspiração marxista contra a religião (identificável como o Inimigo), certo nível de tensão existe entre a religião e, de outro lado, o próprio projeto iluminista e seu processo histórico (de modernização e racionalização). Tal tensão manifesta-se, dessa forma, em algum grau e de diferentes formas (ainda que permitindo acomodações e sínteses), em todas as principais vertentes políticas modernas, inclusive o liberalismo.

Descendo do plano conceitual ou "simbólico" para o nível mais concreto, os conservadores estadunidenses e, no Brasil, os conservadores influenciados por Olavo de Carvalho (como o Padre Paulo Ricardo) veem uma ameaça à "civilização ocidental judaico-cristã" e à alta cultura em pautas como a legalização das drogas, o aborto, o casamento homoafetivo ou até mesmo a 
Lei Maria da Penha (contra a violência doméstica) e a Lei da Palmada ou, no caso estadunidense, o movimento por Direitos Civis dos negros de Martin Luther King Jr. As relações entre cada uma dessas pautas e o pensamento marxista são complexas e, por vezes, até conflituosas - assim como existem ainda tensões e diferenças entre o marxismo e as diferentes vertentes teóricas que embasam os diferentes feminismos, ambientalismos, pós-estruturalismo, teoria Queer e tantos outros.

Contudo, por trás de todas essas "ameaças", a narrativa do "marxismo cultural", tal como esses conservadores o concebem, ganha força explicativa, aglutinando discursivamente linhas de força díspares, e, assim, dá sentido a um mundo que lhes parece caótico.

Embora não seja exatamente algo que possamos chamar de teoria, o "marxismo cultural" possui, portanto, forte densidade semântica e recursos narrativos para a efetivação de projetos autoritários de poder. Tem inspirado movimentos como o Escola Sem Partido, que incentiva alunos a denunciarem seus professores por “doutrinação ideológica". Seu apelo torna-se mais intenso em um momento de crise do modo liberal de organizar a política. Seu edifício ficcional e povoados de inimigos imaginários preenche a imaginação de maneira a dar ao indivíduo o sentimento de poder e de participação do lado certo na guerra do bem contra o mal.

O caso brasileiro é exemplar do alcance e capacidade de efetivação na sociedade por meio de lideranças políticas e religiosas. Mais que isso, o Brasil passa por certo vazio político e pela crise de possibilidades propriamente políticas para a superação da crise. Este momento oferece vagas para que grupos defensores da teoria do "marxismo cultural" ocupem os espaços de poder do Estado. O alcance das consequências começa a ser sentido com a substituição das virtudes de política e da inteligência por tramas imaginárias. 


\section{Referências}

Álvarez, A. L. O. (2017) "Otro catolicismo posible: institución, dios y agentes católicos en las experiencias biográficas de las fieles." Cultura $y$ Religión. 11(1),pp. 4-22.

Amidon, K. S. (2008). "What Happens to Countess Geschwitz? Revisiting Homosexuality in Horkheimer and Adorno." New York Journal of Sociology. 1, pp. 1-24

Arendt, H (1989). Origens do totalitarismo - anti-semitismo, imperialismo e totalitarismo. São Paulo: Cia das Letras

Austin, B S. (sem data) Holocaust Denial: A Brief History. Recuperado em 05 jun 2020 (https://www.jewishvirtuallibrary.org/a-brief-history-ofholocaust-denial)

Azevedo Junior, P. R. de (2011). 01 - Marxismo Cultural e Revolução Cultural: Visão Histórica [Vídeo]. YouTube. https://www.youtube.com/watch?v=FJi7CugwzVw\&feature=youtu.be

Azevedo Junior, P. R. de (2011). 02 - Marxismo Cultural e Revolução Cultural: O Fascismo e o Marxismo Cultural [Vídeo]. YouTube. https://youtu.be/zR46YW9t4VY

Azevedo Junior, P. R. (2011). 03 - Marxismo Cultural e Revolução Cultural: $\begin{array}{llcl}\text { Reação à crise marxista [Vídeo]. } & \text { YouTube. }\end{array}$ https://youtu.be/fb9M8EXdATk

Azevedo Junior, P. R. (2011). 04 - Marxismo Cultural e Revolução Cultural: A infiltração do marxismo cultural no Brasil [Vídeo]. YouTube. https://youtu.be/m1siNc0etwg

Azevedo Junior, P. R. (2011). 05 - Marxismo Cultural e Revolução Cultural: Teologia da Libertação e sua influência na Igreja [Vídeo]. YouTube. https://youtu.be/jG81xG3vHQw

Revista Cultura \& Religión Vol. XV, 2021 № 1 (enero-junio) 215 
Azevedo Junior, P. R. (2011). 06. Marxismo Cultural e Revolução Cultural: Como lutar o bom combate? [Vídeo]. YouTube. https://youtu.be/EkzgEHXPhVI

Berlet, C. (2012). "Collectivists, Communists, Labor Bosses, and Treason: The Tea Parties as Right-Wing Populist Counter-Subversion Panic”. Critical Sociology. 38(4), pp. 565-587.

Callari, A.; Biewener, C.; Cullenberg, S. (eds.) Marxism in the Postmodern Age: Confronting the New World Order. Nova York: Guilford, 1995

Carvalho, O. (2002). Do marxismo cultural. Recuperado em 05 jun. 2019 (http://olavodecarvalho.org/do-marxismo-cultural)

Carvalho, O. (2006). O sucesso do fracasso. Diário do Comércio, 27 nov. Recuperado em 05 jun. 2020 (http://old.olavodecarvalho.org/ semana/061127dc.html)

Carvalho, O. (2008). URSS, a mãe do nazismo. Diário do Comércio, 11. dez. Recuperado em 06 ago.2019 (https://olavodecarvalho.org/urss-a-maedo-nazismo/)

Carvalho, O. (2019). Escola de Frankfurt, Música Rock e Beatles e etc... [Vídeo]. Youtube. https://www.youtube.com/watch?v=CKxs2F6bdI0

Carvalho, O. (2013). Duas perguntas. Diário do Comércio. 9 abr. Recuperado em 03 set.2019 (http://old.olavodecarvalho.org/semana/130409dc.html)

Carvalho, O. (2016). Maquiavel ou a Confusão Demoníaca. Campinas: Vide Editorial.

Carvalho, O. (2017). COF Aula 237 [Video]. YouTube. https://youtu.be/K4AvvvTpl5c

Cheatle, L. \& Toub, M. (Diretores) (2000). From Swastika to Jim Crow Black-Jewish Relations (documentário). PBS: Public Broadcasting $\begin{array}{lllll}\text { Service. } & \text { Recuperado em } 4020\end{array}$ https://web.archive.org/web/20150722212600/ Recuperado em http://www.pbs.org/itvs/fromswastikatojimcrow/relations.html 
Cipriani, R. (2013). "La religión en el espacio público". Revista Cultura y Religión. 7(2). Santiago, pp. 171-183.

Crick, B. (1981). Em defesa da política. Brasília: UnB.

Dickson, J. (2020). “Georg Lukács and the Leap of Faith”. The European Legacy. 25(6), pp. 613-634. Recuperado em 8 set. 2020 (https://doi.org/10.1080/10848770.2020.1756596)

Drolet, J.-F. (2020). "America first: paleoconservatism and the ideological struggle for the American right”. Journal of Political Ideologies, 25 (1m). Recuperado em 01 nov. 2020 (https://www.tandfonline.com/ doi/full/10.1080/13569317.2020.1699717)

Dworkin, D. (1997). Cultural Marxism in Post-war Britain: History, the New Left and the Origins of Cultural Studies. Durham, NC: Duke University Press.

Epstein, B. R.; Forster, A. (1966). Report on the John Birch Society. Chicago: Random House.

Erriguel, A. (2018). Deconstrucción de la izquierda posmoderna. Recuperado em 03 ago. 2020 (https://elmanifiesto.com/tribuna/6104/deconstruccionde-la-izquierda-posmoderna-i.html)

Ferreira, M. R. (2017). A Escola de Franfkurt: satanismo, feiura e revolução. Recuperado em 28. Jul 2020 (http://estudosnacionais.com/cultura/escola -de-franfkurt-satanismo-feiura-e-revolucao/).

Fidelio Magazine (1992). Inverno, p. 1. Recuperado em 01. Dez. 2020 (https://archive.schillerinstitute.com/fid_97-01/fidelio.html)

Foley, M. (2007). American Credo: The Place of Ideas in US Politics. New York: Oxford University Press.

Forlenza, R. (2019). “Antonio Gramsci on religion”. Journal of Classical Sociology. 21(1). pp. 38-60. Recuperado em 02 ago.2020 (https://doi.org/10.1177/1468795X19865119)

Fusaro, D. (2012). Minima mercatalia. Filosofia e Capitalismo. Milão: Bompiani.

Revista Cultura \& Religión Vol. XV, 2021 № 1 (enero-junio) 217 
Geertz, C. (1983). Local knowledge: Further essays in interpretive anthropology. New York: Basic Books.

Gilbert, H. (2003). Lyndon LaRouche: Fascism Restyled for the New Millennium. Seattle: Red Letter Press.

Goldberg, J. (2009). Liberal Fascism: The Secret History of the American Left, from Mussolini to the Politics of Change. New York: Broadway Books.

Gottfried, P. (1993). The Conservative Movement. Boston: Twayne Publishers, 1993.

Harvey, D. (1992). Condição pós-moderna. São Paulo: Loyola.

Hopkins, D. (2017). Who's Winning the Culture War? Corporate America. New York Times, 27 dez. Recuperado em 20 jul. 2019 (https://www.nytimes.com/2017/12/27/opinion/culture-war-corporateamerica.html)

Horkheimer, M. \& Adorno, T. (2002). Dialectic of enlightenment: Philosophical Fragments. Stanford, California: Stanford University Press.

Jackson, T. F. (2007). From Civil Rights to Human Rights: Martin Luther King, Jr. and the Struggle for Economic Justice. Philadelphia: University of Pennsylvania Press.

Jamin, J. (2018). "Cultural Marxism: A survey”. Religion Compass. 12(1-2). pp. 10-27. Recuperado em 2 nov. 2020. (e12258. doi:10.1111/rec3.12258).

Jay, M. (2010) "Dialectic of Counter-Enlightenment: The Frankfurt School as Scapegoat of the Lunatic Fringe”. Salmagundi, 168/169 (Fall 2010Winter 2011), pp. 30-40. Recuperado em 3 nov. 2020 (http://www.jstor.org/stable/41638676)

Koselleck, R. (2014). Estratos do tempo: estudos sobre história. Rio de Janeiro: PUC-Rio 
Kovel, J. (2010). "Wilhelm Reich: A Harbinger of Ecosocialism? An Introduction to Bennett". Capitalism Nature Socialism, 21(1), pp. 41-52. (doi:10.1080/10455751003655864)

Lima, M. R. S. de (2019). “O Estilo Bolsonaro de Governar e a Política Externa". Boletim OPSA ISSN 1809-8827, 1 (Jan./Mar), s/ paginação.

Lind, W. S. (2007). Who stole our culture? Recuperado em 09 ago. 2020 (http://www.thephora.net/forum/archive/index.php/t-40406.html)

Lind, W. S. (2000). The Origins of Political Correctness. Recuperado em 01 ago. $2020 \quad$ (https://www.academia.org/the-origins-of-politicalcorrectness/)

Lipstadt, D. (1994). Denying the Holocaust: The Growing Assault on Truth and Memory. Plume: New York.

Mansilla, H. C. F. (2007) "La dialéctica de fe y razón em el mundo contemporáneo". Cultura y religión. 1(2) (https://www.revista culturayreligion.cl)

Mello, L. (2019). “Acusado de plágio, coordenador do Enem fala em 'tradução adaptada: Internautas apontaram semelhanças entre texto de Murilo Resende sobre a Escola de Frankfurt e artigo de 1992”. Veja, 19 jan. Recuperado em 05 ago. 2019 (https://veja.abril.com.br/politica/acusadode-plagio-coordenador-do-enem-fala-em-traducao-adaptada)

Minnicino, M. J. (1992). "The Frankfurt School and 'Political Correctness"”. Fidelio: Journal of Poetry, Science, and Statecraft, Washington, DC, 1 (1), pp. 2-27. Recuperado em 15 jul. 2019 (https://archive.schillerinstitute.com/fidelio_archive/1992/fidv01n011992Wi/fidv01n01-1992Wi.pdf)

Müller-Doohm, S. (2005). Adorno: A Biography. Malden, MA: Polity Press.

Nesti, A. (1975). Gramsci et la religion populaire. Social Compass. 22(1975/3-4), pp. 343-354.

Netto, J. P. (2009). O que é Marxismo. São Paulo: Brasiliense.

Revista Cultura \& Religión Vol. XV, 2021 № 1 (enero-junio) 219 
Nyquist, J. (2014.). O psicopata (que não está mais) embaixo da cama - Parte III. Recuperado em 8 maio 2020 (https://midiasemmascara.net/opsicopata-que-nao-esta-mais-embaixo-da-cama-parte-iii/)

Ortiz, R. (2006). "Notas sobre Gramsci e as ciências sociais". Revista Brasileira de Ciências Sociais. 21(62), pp. 95-103. Recuperado em 03 set. 2020. (https://doi.org/10.1590/S0102-69092006000300007)

Otterman, M. (2007). American Torture: From the Cold War to Abu Ghraib and Beyond. Melbourne: Melbourne University Publishing.

Pluckrose, H. (2018). “'Cultural Marxism' is a Myth. The Threat Comes from Elsewhere". Areo, 30 out. Recuperado em 03 ago. 2020 (https://areomagazine.com/2018/10/30/cultural-marxism-is-a-myth -the-threat-comes-from-elsewhere)

Rosenberg, P. (2019). “A user's guide to 'Cultural Marxism': Anti-Semitic conspiracy theory, reloaded: How an arcane conspiracy theory from the far-right margins is fueling terrorism - and Donald Trump's Twitter feed". Salon, 05 mai. Recuperado em 01 jun. 2020 (https://www.salon.com/2019/05/05/a-users-guide-to-cultural-marxismanti-semitic-conspiracy-theory-reloaded)

Saldaña, P. (2019). "Vélez exalta igreja e família e diz que MEC vai combater marxismo cultural: Ministro disse que o MEC vai priorizar a educação básica, sobretudo a alfabetização". Folha de São Paulo, 05 jan. Recuperado em 13 jul. 2020 (https://www1.folha.uol. com.br/educacao/2019/01/velez-exalta-igreja-e-familia-e-diz-que-mecvai-combater-marxismo-cultural.shtml)

Schmitt, C. (1992). O conceito do político. Petrópolis: Vozes.

Scruton, R. O que é conservadorismo. São Paulo: É Realizações, 2015

Severo, R. (2019). "Lyndon LaRouche, Cult Figure Who Ran for President 8 Times, Dies at 96". New York Times, 13 fev. Recuperado em 07 jul. 2020 (https://www.nytimes.com/2019/02/13/obituaries/lyndon-larouchedead.html)

Revista Cultura \& Religión Vol. XV, 2021 Nº 1 (enero-junio)

220

Silva, Wellington T., Sugamosto, A. e Irigaray A., U. (2021). O marxismo cultural no Brasil: origens e desdobramentos de una teoría conservadora. Revista Cultura \& Religión, 15 (1), 180-222 
Socha, E (2019). "Para um conceito materialista de tempo musical. A teoria dos tipos nos fragmentos de Adorno sobre Beethoven”. Discurso, 49(1) pp. $161-184$

SPLC (Southern Poverty Law Center) (2002). "Ally of Christian Right Heavyweight Paul Weyrich Addresses Holocaust Denial Conference”. Intelligence Report. Fall Issue. Recuperado em 02 dez. 2020 (https://www.splcenter.org/fighting-hate/intelligence-report/2002/allychristian-right-heavyweight-paul-weyrich-addresses-holocaust-denialconference)

Tajra, A. \& Andrade, H. (2019) 'Novo ministro critica 'marxismo cultural' nas escolas: 'faz mal à saúde'...”. UOL, 02. jan. https://noticias.uol.com.br/politica/ultimas-oticias/2019/01/02/ministroda-educacao-cita-deus-e-critica-marxismo-cultural-nas-escolas.htm?fbc lid=IwAR19uCgvppeWcS3u-rSznh3kO4eIefiKP2oYCBJDFgyAXI_hIBLMncfhb0

Valodzin, U. (2020). "Criminal prosecution of homosexuals in the Soviet Union (1946-1991): numbers and discourses". Working Paper, EUI HEC, 2020/02. Cadmus, European University Institute Research Repository. $\begin{array}{llllll}\text { Recuperado em } & 30 \quad \text { dez. } & 2020 . \quad \text { (http:/diana- }\end{array}$ n.iue.it:8080/handle/1814/67530)

Velasco, J. (2020). "You are Cancelled: Virtual Collective Consciousness and the Emergence of Cancel Culture as Ideological Purging”. Rupkatha Journal on Interdisciplinary Studies in Humanities, 12(5) p.48-68.

Wendling, M. (2018). Alt-Right: From 4chan to the White House. London: Pluto Press.

Wertz, W. F. (1992). "For A New Golden Renaissance". Fidelio: Journal of Poetry, Science, and Statecraft. 1(1), pp. 2-3. Recuperado em 01 ago. 2020 (https://archive.schillerinstitute.com/fidelio_archive/ 1992/fidv01n01-1992Wi/fidv01n01-1992Wi.pdf) 
Witkin, R. W. (2000). "Why Did Adorno 'Hate' Jazz?" Sociological Theory, 18(1), pp. 145-170. Recuperado em 6 maio 2020. (doi:10.1111/07352751.00092)

Zetkin, C. (1956). Lênin e o Movimento Feminino. Recuperado em 7 out. 2020 (https://www.marxists.org/portugues/zetkin/1920/mes/lenin.htm)

Žižek, S. (2002). Did Somebody Say Totalitarianism?: Five Interventions in the (Mis)use of a Notion. London and New York: Verso

Zuckert, C. H. \& Zuckert, M. P. (2008). The Truth about Leo Strauss: Political Philosophy and American Democracy. Chicago: University of Chicago Press.

Zulendrys, K. A. (2010). “Algunas consideraciones sobre la actuación jurídica ante la solución de los conflictos de las personas LGBT: una mirada crítica desde Cuba". Revista Sexología y Sociedad, 16(45), pp. 33-66. Recuperado em 2 out. 2020 (http://revsexologiaysociedad.sld.cu/ index.php/sexologiaysociedad/article/view/409/449)

\footnotetext{
* Doutor em Ciência da Religião pela UFJF. Estágio pós-doutoral em História - UFMG. Professor Programa de Pós-Graduação em Ciências da Religião da PUC Minas (Minas Gerais, Brasil).wteodoro@pucminas.br

** Mestre em Ciências da Religião - PUC Minas. Doutorando em Ciências da Religião - PUC Minas.sugamosto@gmail.com

**** Mestre em Literatura Comparada pela UnB, Doutorando em Antropologia Social pela UnB, pesquisador do INCT/INEAC. urielaraujo@ hotmail.com
} 